\title{
離岸流の非定常過程の センシング手法に関する研究
}

\author{
児島 正典 1 - 武若 聡 2 \\ 1 学生会員 筑波大学システム情報工学研究科（テ305-8573 茨城県つくば市天王台 1-1-1） \\ 2 正会員 筑波大学教授 システム情報工学研究科（同上）
}

\begin{abstract}
Xバンドレーダで砕波帯を観測し，離岸流の非定常な発達過程を遠隔から観測する手法について検討し た.レーダ画像には, 離岸流の発生と共に沖側に移動する流れの先端部（リップヘッド）が捉えられる. これを追跡する画像解析プログラムを開発し，その妥当性を検証した. 6 ケ月にわたる観測結果を分析し， 離岸流の諸元（発達早さ，発生数等）と，海況（波浪，潮汐）の関連性を調べた。離岸流の発生条件に ついては既存の報告と整合する結果が得られた.
\end{abstract}

Key Words : Rip current, image processing, remote sensing, X-band radar

\section{1. はじめに}

離岸流は毎年発生する海難事故の原因として知られて おり，その発生を察知することは防災上重要である．離 岸流の発生を観測する手法としては，流速計を用いて直 接検出するものや, GPS フロートや染料を海面に放流し てその動きを見る方法が知られている ${ }^{1), 22}$. これらの方 法には，一回の観測ごとに人の手が必要である，同時に 広範囲を観測するのが難しい等の難点が存在する.

過去の研究により，海岸に設置したXバンドレーダの 観測画像中に現れる筋状のパターンと離岸流の発生に相 関があることがわかっている．Xバンドレーダは無人で 長時間・広範囲の観測が可能な機材であり，これを利用 することにより海岸の常時監視による防災が実現できる と考えられる.

本研究では，Xバンドレーダ画像を解析して離岸流の 発達および発生数を検出するプログラムを作成し，その 妥当性を検証した.これによって離岸流の諸元(発生数,

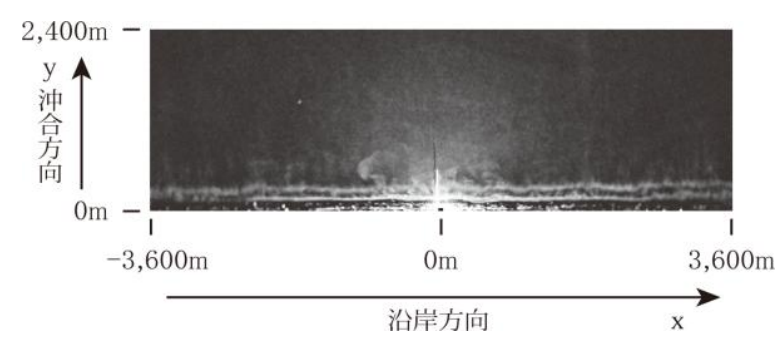

図-1 レーダ平均画像

(2014 年 2 月 24 日 15 時 50 分)
2014/2/24/19: 48

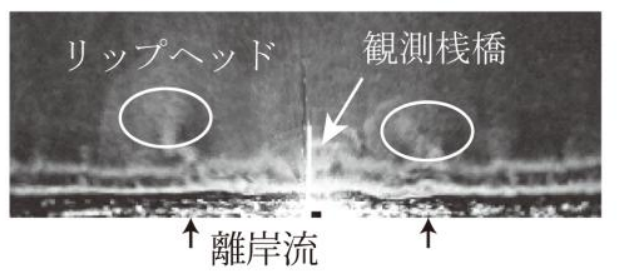

$2014 / 2 / 24 / 19: 50$

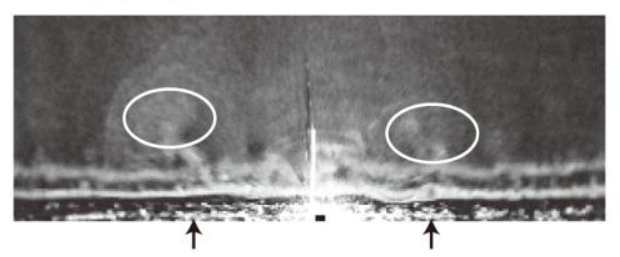

$2014 / 2 / 24 / 19: 52$

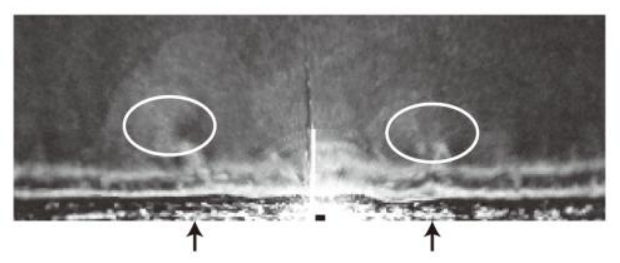

2014/2/24/19:54

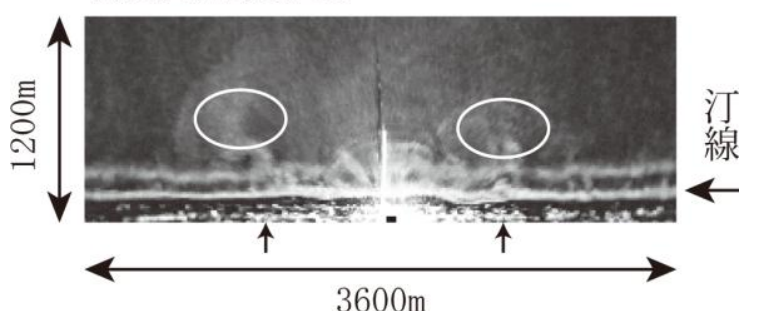

図- 2 レーダ画像中の離岸流パターン (2014 年 2 月 24 日 19 時 48 分〜54 分, 図中の楕円形はリップヘッド位置) 


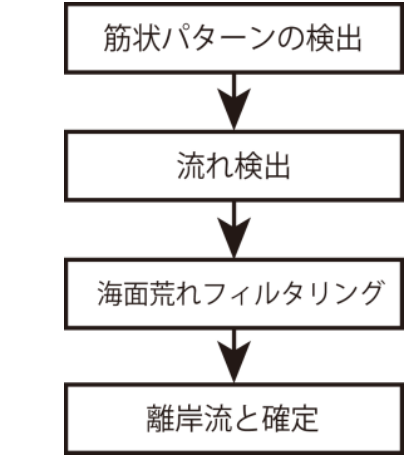

図-3＼cjkstart離岸流検出のフローチャート

発達早さ等）を調べ，海況（波浪，潮汐）との関連を調 ベた.

\section{2. 観測とレーダ画像}

$\mathrm{X}$ バンドレーダ観測は，茨城県神栖市の波崎海岸にあ る港湾空港技術研究所の波崎観測栈橋 HORS で行った. 沿岸方向, 沖合方向それぞれ約 $15,360 \mathrm{~m}$ の範囲のエコー データを 2 秒毎に収集し，これを毎時 30 分から 56 分に 2 分毎に平均化した画像を作成した．本研究では，観測 地点周辺の $600 \times 200$ ピクセル $(7,200 \mathrm{~m} \times 2,400 \mathrm{~m})$ を解析 対象とする. 1 ピクセルは約 $12 \mathrm{~m}$ 四方に相当し, 輝度が 相対的なレーダーエコーの強度に比例する. 観測は 2014 年1月9日から 6 月 24 日までの期間にかけて行った。図 -1 にレーダで得られた平均画像の一例と座標系を示す.

先の研究において ${ }^{1)}$, GPS フロートを用いた離岸流観 測の結果とレーダ画像の比較により，レーダ画像中に現 れるパターンが離岸流の発生と相関していることが示さ れている. 図-2にレーダ画像中に捉えられた 6 分間の離 岸流パターンの発達の例を示す．離岸流の発生を示す煙 状のパターンが汀線から伸び、離岸流の先端部であるリ ップヘッドが約 $5 \mathrm{~m} /$ 分の速度で沖に向かって発達してい く様子が捉えられている.

\section{3. 離岸流の検出方法}

\section{1 検出の概要}

過去の研究において、レーダ画像中の離岸流パターン を目視で検出する方法が採られている ${ }^{2)}$. これに対し， コンピュータによる画像解析を行い，離岸流パターンを 自動的に検出する手法を開発した。レーダ画像中の離岸 流パターンを検出するためのフローチャートを図-3に示 す. 1 枚のレーダ画像のみを判断材料として目的パター ンとそれ以外の海洋事象によるノイズを区別することは 難しいため, 時系列順に並んだ複数の画像を参照し，時

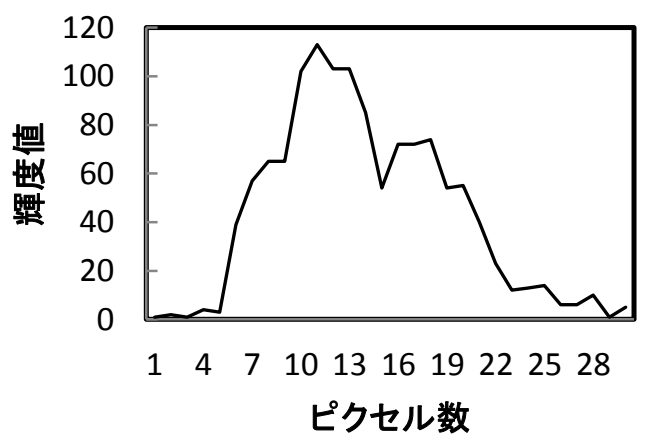

図-4 䇗状パターン存在部分の輝度值分布例

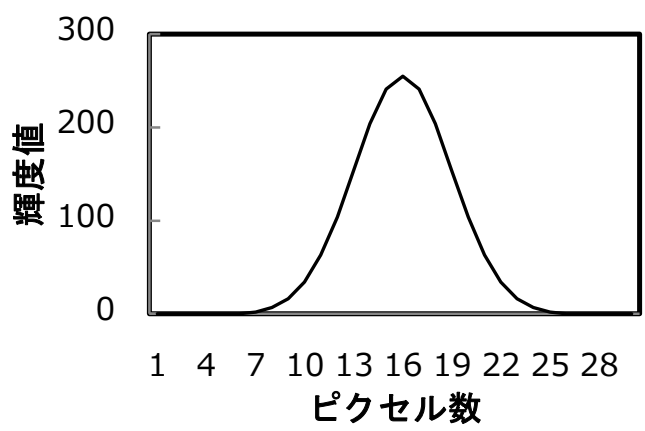

図-5 筋状パターン検出用フィルタ

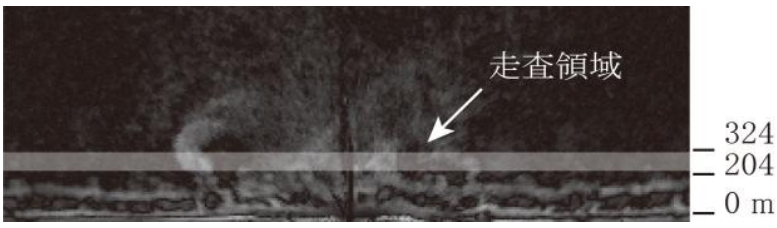

図-6 筋状パターン検出フィルタの走査領域

間に伴う変化を海面の流れとして検出する方法を考えた 雨や風によって海面が荒れている場合，流れを検出する ための相関係数が目的パターン以外のノイズを誤検出す る場合があるため，フーリエ変換によって目的領域のパ ワースペクトル画像を作成し，高周波成分の割合が高い 場合は非検出とした。

離岸流を検出する際には，目的画像と 2014 年 1 月 9 日〜6月 24 日の平均画像の差を取った差分画像を作成し, これを解析の対象とした。

\section{2 筋状パターンの検出}

図-4 に離岸流の筋状パターンの現れている部分を沿岸 方向にスライスした輝度值分布の例を示す．パターンが 現れている座標を中心に沿岸方向 30 ピクセル分の輝度 值分布を表している. パターンが現れている部分は山型 の輝度值分布を示していることが確認できる 


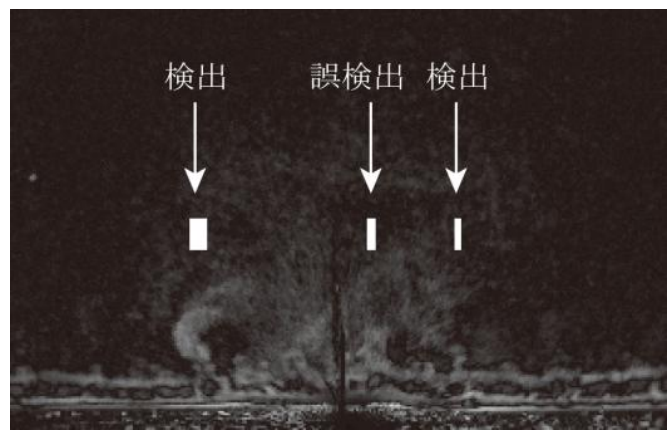

図-7 筋状パターン検出画像

(2014年 2 月 24 日 15 時 34 分)

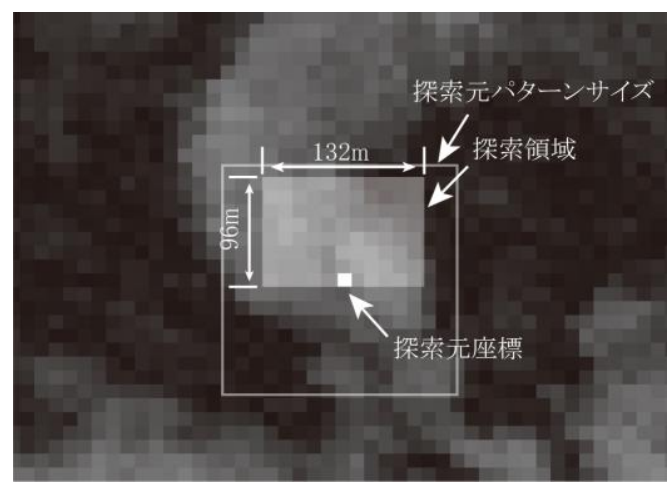

図-8 流れ探索の様子

(2014 年 2 月 24 日 15 時 36 分 $\mathrm{x}:-864 \mathrm{~m}$ y:324 m)

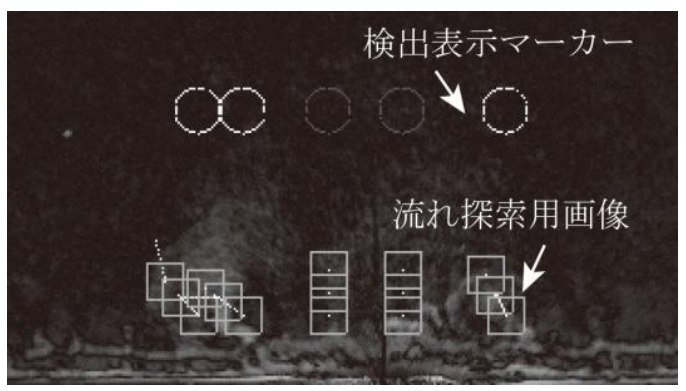

図-9 離岸流検出の様子

(2014年 2 月 24 日 20 時 44 分)

図-5 に筋状パターンを検出するために作成した一次元 フィルタを示す。フィルタはいくつかの離岸流パターン をもとに，正規分布関数を使ったものを用いた. フィル 夕の信号長は, 幅が数十 $\mathrm{m}$ におよぶ離岸流を 2 分間観測 した結果表れるパターンの幅を不足なく含むため, 30 ピ クセル（約 $360 \mathrm{~m} ）$ とした. フィルタと目的パターンの 相関度は相互相関係数を用いて調べた.

図-6 に筋状パターン検出フィルタの走査領域を示寸. 汀線から沖合方向に約 $200 \mathrm{~m}$ までの範囲は砕波帯であり， 輝度の変化が激しく検出には向かないため, 海岸方向の 一つの地点に対して沖合方向 $204 \mathrm{~m} \sim 324 \mathrm{~m}$ の間（10 ピ クセル分）を対象領域として走査を行う。走査した 10 ピクセル分のうち，5回以上検出された場合のみ検出が

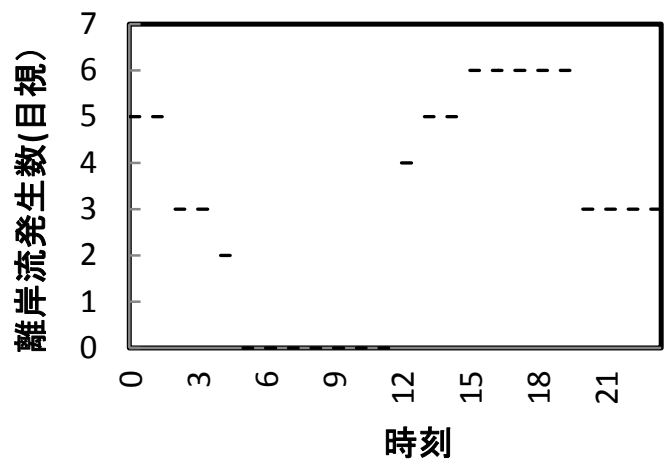

図-10 離岸流発生数（目視）（2014 年 2 月 24 日）

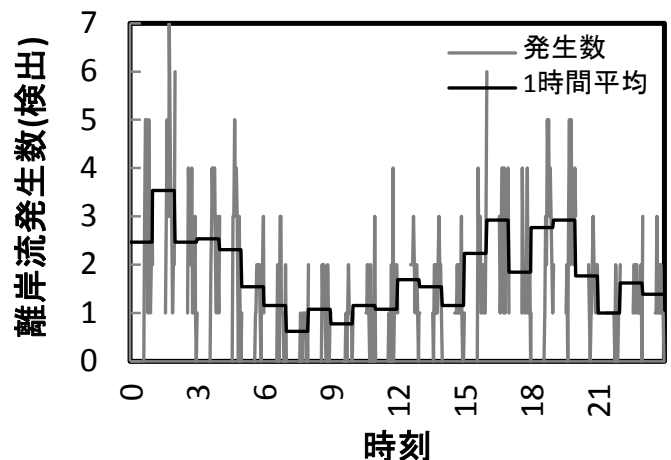

図- 11 離岸流発生数（検出）（2014 年 2 月 24 日）

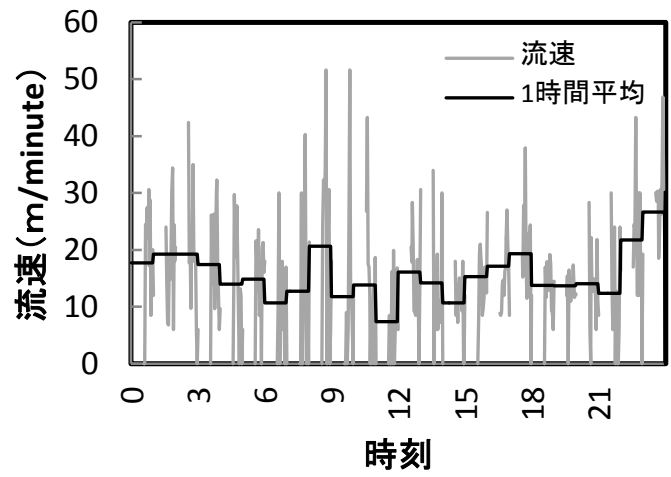

図-12 離岸流平均流速（2014 年 2 月 24 日）

確定されるものとした。

図-6 のレーダ画像にフィルタを適用したところ，筋状 パターンが表れている部分の相関度は 0.613175 ，表れて いない部分は-0.28175 となった。このことから，相関係 数の值が 0.5 以上となった場合に検出がされたとした.

上記の手法で筋状パターンの検出を行った結果画像 を図-7に示寸，パターンが検出された箇所は上方に幅 1 ピクセルの白い縦線が示されている.

目的の筋状パターンを不足なく検出できていること がわかるが，中心付近にある不明瞭なパターンを誤検出 している.また，一つのパターンを重複して複数回検出 
していることがわかる．これを踏まえて，次の流れ検出 において,一回の検出ごとに 30 ピクセル以上の間隔を空 けて検出を行うこととした。

\section{3 流れ検出}

時系列画像の解析によって離岸流の流れを検出する手 法について説明する．ある時点での目的画像について， 筋状パターンを検出した目的座標の周辺から正方形の流 れ探索画像を切り出寸. 次に, 2 分後の目的画像（次フ レーム画像）の目的座標周辺から同様に正方形の探索対 象画像を切り出し, 2 枚の正方形画像の相関值を調べる. この操作を次フレーム画像の目的座標の周辺座標全体に ついて行い，最も相関值の高かった周辺座標を流れの移 動先座標とする．相関值は画像のパターンマッチング手 法に広く用いられる二次元相互相関係数 ${ }^{3)}$ で調べるもの とした.

図-8に流れ探索画像の例を示寸. 画像は $16 \times 16$ ピクセ ル（192 m 四方）からなる．流れ移動先座標と目的座標 の差の絶対值を流れ速度と寸る．離岸流の流速は一般的 に $0.5 \mathrm{~m} /$ 秒程度であると言われていることから，探索領 域は沿岸方向に-66 m〜 66 m, 沖合方向に $0 \mathrm{~m} \sim 96 \mathrm{~m}$ とし た．相関值の閾值を 0.5 とし，探索領域全体において相 関值が閾值未満だった場合，非検出とする．海面の細か い乱れに反応してノイズを検出するのを防ぐため，探索 対象パターンの最大輝度值が 40 以下の場合は非検出と する.

実際の検出では，一つの筋状パターンに対して 3 個の 流れ探索画像を用意し, 汀線加ら $336 \mathrm{~m}$ の地点を初期位 置として沖合方向に $120 \mathrm{~m}$ ごとの等間隔で並べるものと した. 3 個のパターンはそれぞれ独立して流れの探索を 行い，3 個のうち 1 個以上が流れを検知寸れば離岸流を 検出したとみなす。，一度流れを検出した後は，3 個の流 れ方向ベクトルを平均した方向に流れ探索画像列の角度 をフィッティングし，角度のついた離岸流に対応寸る.

\section{4 海面の荒れの検出による誤判定の排除}

雨天時や荒天時に海面に発生する細かい荒れを離岸流 として誤検出する場合がある．これを防ぐため，流れ探 索対象画像をフーリエ変換し，パワースペクトル画像全 体に対する高周波成分の割合を調べることで，海面荒れ による誤判定を排除した。 具体的には，パワースペクト ル画像の高周波成分の輝度值を合計し，パワースペクト ル画像全体の合計值で割った值で海面の荒れの程度を判 別した.

図-9 にすべての処理を適用した離岸流検出の様子を 示す．画像中の矩形は流れを探索するための空を，矩形 中心から伸びる線分は流れベクトルを，上部の白い丸印 は離岸流を検出した位置を表している．色の薄い丸印は
離岸流として確定されていない離岸流候補を表している. 一つの離岸流候補に対して 3 個の流れ探索用空を用意し, 2 分前, 2 分後に取得された画像と比較することで流れを 検出している. 図-9では 3 つ離岸流を検出している.

\section{5 検出結果}

図-10 にレーダ平均画像から目視で読み取った離岸流 の発生数を，図-11にプログラムで検出した発生数を示 寸. 発生数は, 1 枚のレーダ画像から検出された離岸流 パターンの数とする. 離岸流が検出されなかった場合, 発生数は 0 とする. 目視による検出とプログラムによる 検出はともに汀線方向に-3,600 $\mathrm{m}<\mathrm{x}<3,600 \mathrm{~m}$ の範囲で, 毎時 30 分 56 分の間の 2 分毎に行った. プログラムに よる検出は，パターンの途切れによる検出漏れやノイズ による誤検出があるものの，発生数の変化のトレンドを 捉えていることが分かる.

図-12 に検出された離岸流の平均流速を示寸。平均流 速は画像中のパターンの移動速さの平均值で定義する. 離岸流が検出されていない場合の流速は 0 になっている。 離岸流の平均流速は分速約 $15 \mathrm{~m}$ 程である. 先の研究で 観測された離岸流の速度は毎分 $10 \mathrm{~m}$ 30 m 程度であり, この結果と整合する ${ }^{2)}$.

\section{4. 離岸流の発生条件}

プログラムによって検出された離岸流と海象条件，気 象条件との比較を行った。

図-13に 2014 年 2 月 24 日の銚子漁港の潮汐の変動を 示寸 ${ }^{4}$. 図-11 に示した発生数の変化と比較すると, 離岸 流の発生数は満潮時に少なく干潮時に多くなる傾向が見 られる. 図-12 に示した離岸流速度と比較すると，流速 は満潮時に小さく干潮時に大きくなる傾向が見て取れる 山川 ${ }^{2}$ は潮位と離岸流の発生に同様の関係があることを 示している.

図-14に 2014 年 2 月 15 日から 28 日までの二週間にわ たる潮位の変動，図-15 に同期間中の沿岸部での波向と 波高，図-16 に同期間中の沿岸部での風向と風速，図-17 に同期間中に検出された離岸流の発生数，図-18 に同期 間中に検出された離岸流速度を示す。沿岸部の波向と波 高，風向と風速には気象庁の沿岸波浪数值予報モデルの 結果 ${ }^{5}$ を用いた。 この予報データを用いるのは，今後， 離岸流予測に展開寸るための検討を兼ねたものである.

図-14 を図-17，図-18 と比較すると，潮位の変動が大 きくなる 15 日〜 17 日の範囲で離岸流の発生数と流速が 大きくなる傾向が見られる，一般に，潮位の変動が大き い時に離岸流が発生しや寸くなるとされており，結果は これと整合する。

図-15 中の波向は、北からの入射が 0 度，東からの入 


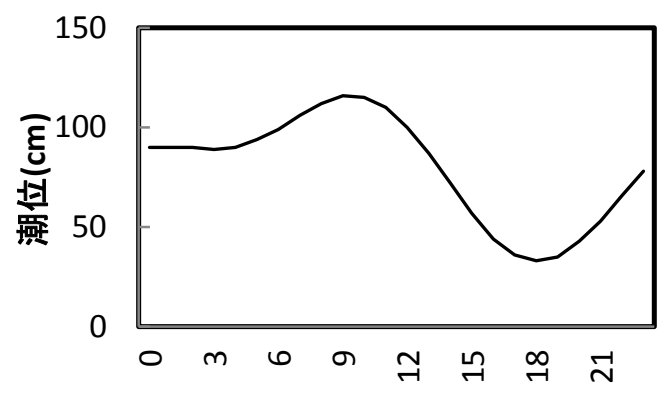

時刻

図-13 潮位の変化

(2014 年 2 月 24 日， 銚子漁港，観測基準面からの高さ)

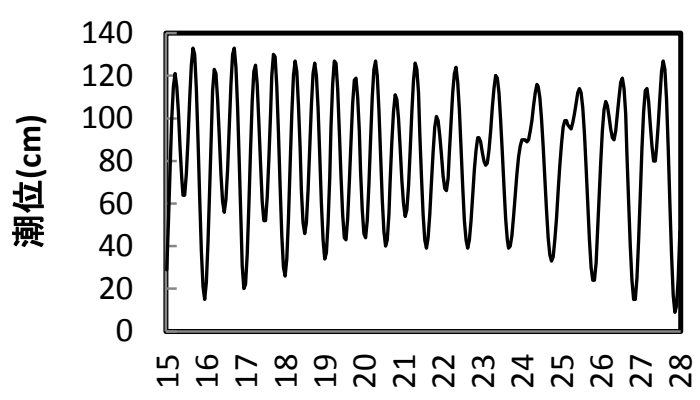

日付

図-14 潮位の変化

(2014年 2 月 15 日～28 日，銚子漁港）

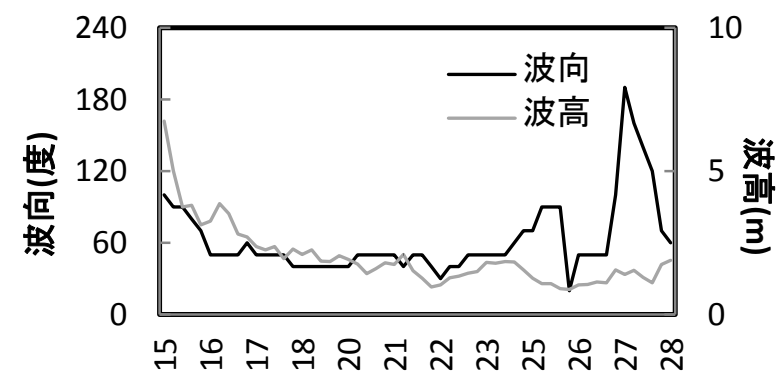

日付

図-15 沿岸部の波向と波高

(気象庁, 沿岸波浪数值予報モデル)

(2015年 2 月 15 日 28 日)

射が 90 度である. 波崎海岸線は東西方向に対して約 60 度の角度をなしており, 波向 60 度の波は海岸にほぼ直角 に入射する. 図-17，図-18 と比較寸ると，比較的波高の 大きく, 波向が海岸に対して直角に入射する $60^{\circ}$ に近い 15 日～17 日の範囲で離岸流の発生数と流速が大きくな り，波向が斜め入射になる 25 日〜28 日付近では発生数 と流速が小さくなっていることが示されている。一般に 波が直角入射すると離岸流が発生しや寸いとされており， これと整合する.

図-16に同期間中の沿岸部での風向と風速を示寸，風

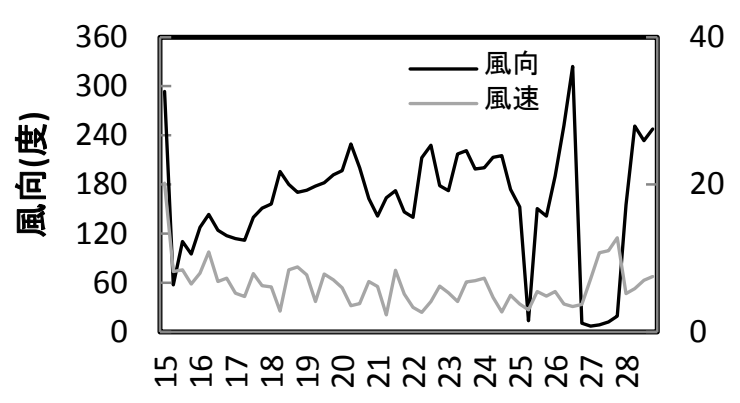

日付

図-16 沿岸部の風向と風速

(気象庁，沿岸波浪数值予報モデル)

（2014年 2 月 15 日〜28 日）

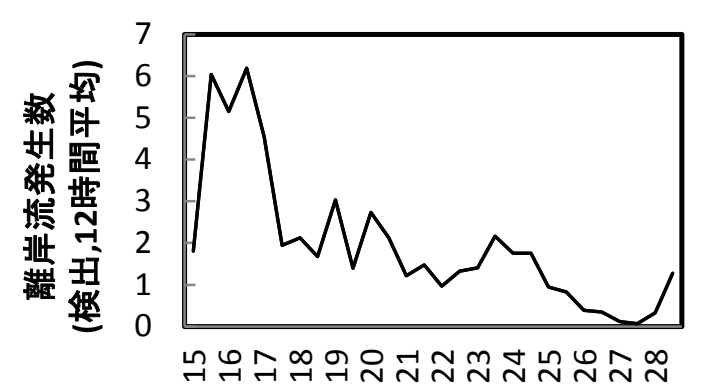

日付

図-17 離岸流発生数

(2014 年 2 月 15 日～28 日)

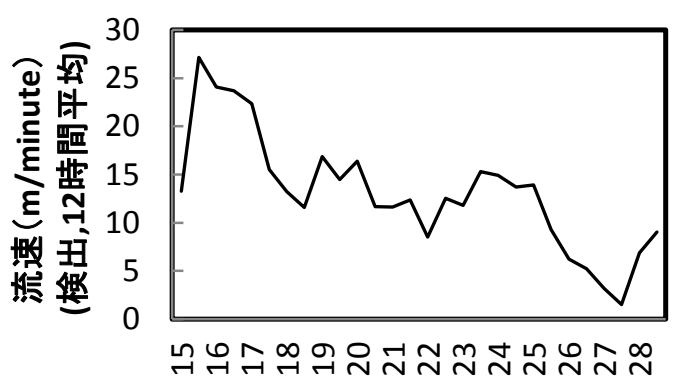

日付

図-18 離岸流速度

(2014 年 2 月 15 日～28 日)

向は波向と同様，60 度の時に海岸線に直交して吹く. 図-17 と比較すると, 風向が 60 度に近い時に離岸流が 多く発生するのに対して, 陸風の 240 度となるとほとん ど発生していないことがわかる. 離岸流は, 沖から吹き 込む風によって陸向きに輸送される水塊が沖に戻ろうと することで発生すると説明されることもあり，これと整 合する.

\section{5. 結論}

$\mathrm{X}$ バンドレーダの観測結果より離岸流の非定常な発達 
過程を追跡するアルゴリズムを開発し，プログラムを作 成してその妥当性を確認した. 離岸流の諸元と海況の関 係を比較し, 離岸流の発生と潮汐に一定の関係があるこ とを確認した. 今回の提案手法では直線状の海岸につい てのタ検証を行ったが，簡単な変更を行うことで入り組 んだ海岸地形にも適用可能であると考えられる.

この手法を発展させ，気象条件や海象条件も判断条件 に加えれば，より信頼性の高い離岸流検知が可能になる と考えられる.これに向けて，より多様な海象条件下で の離岸流観測とレーダ観測の比較，性能の高い画像解析 アルゴリズムの開発などが必要である.

\section{参考文献}

1) 山川泰司, 武若聡 : $X$ バンドレーダを用いた離岸流の発 生探知に関する検討, 海岸工学論文集, 第 54 巻, pp. 1436-1440, 2007.
2) 山川泰司, 武若聡, 桜井崇, 柳嶋慎一 : 離岸流観測への Xバンドレーダ利用に関する検討, 海岸工学論文集, 第 55 巻, pp. 91-95, 2008.

3) Adrian Kaehler, Gary Bradski : 詳解 OpenCV ーコンピュ ータビジョンライブラリを使った画像処理·認識, オライ リージャパン， 2009.

4) 気象庁, 潮位表 銚子漁港, http://www.data.jma.go.jp/kaiyo $\mathrm{u} / \mathrm{db} /$ tide/suisan/suisan.php?stn=CS

5) 気象業務センター：沿岸波浪数值予報モデル, GPV (CW M), http://www.jmbsc.or.jp/hp/online/f-online3t.html

\section{A STUDY ON RIP CURRENT DETECTION BY RADAR IMAGE ANALYZE}

\section{Masanori KOJIMA and Satoshi TAKEWAKA}

X-band radar measurements have been applied for rip current observation. Radar images were collected at research pier HORS on a straight sandy coast. Time averaged images of every 2 minutes have been processed, which frequently display characteristic cross-shore patterns that resemble to neck and head of a rip current. An image analysis program is developed to detect rip current occurrence and estimate migration speed of rip heads. Results were compared with manually inspected results of the radar images, and fairly well agreement was confirmed. Results of the detection are correlated with tide and weather conditions. 